\title{
An Analytical Study on the Use of Electronic Resources by the Students and Research Scholars of Annamalai University, Tamil Nadu
}

\author{
K.Vijayakumar \\ Assistant Professor (S.G), Department of Library and Information Science, \\ Annamalai University, Annamalai Nagar, Tamil Nadu, India \\ E-mail: dr.vijay-1973@rediffmail.com
}

\begin{abstract}
This paper deals with E-resources such as E-book, E-journals, E-papers. Most of the students and scholars using the E-resources. E-resources plays an important role in the library and information science. Opinions regarding Frequency of library visit of the users, E-resources usage were gathered from 250 users out of which 200 valid questionnaire received from the scholars.

Keywords: E-resources, E-books, E-papers, E-encyclopedia, Etheses etc.
\end{abstract}

\section{INTRODUCTION}

Development in Electronic publishing can be used efficiently and effectively to provide information to users pin-pointedly, exhaustively and in time. Today libraries are surrounded by networked data that is connected to vast ocean of internet based services.

Electronic information resources (or) simply electronic resources (E-resources) are information stored in electronic format in computer (or) computer related facilities (CDROMs, flash drives, digital libraries (or) the internet). Thus, Haridasan and Khan had defined electronic information resources as resources in which information is stored electrically and which are accessible through electronic system and networks.

\section{REVIEW OF LITERATURE}

Okonoko Vera Ngozi, et.al (2015) investigated the information seeking behavior of faculty members of the Federal University of petrol resources (FUPRE), The population of the study was the full time faculty members in FUPRE, The research finding shows that the respondents use books (print\& online) as their preferred source of informations.

Mostofa, S.K Mamum, (2013) focused on how electronic information resources influence the information seeking process in the different faculty members of Darullshan University.

Khan and Dominic (2012) the use of the internet is vital in research in every university, they conducted a survey to assess the extent of internet use by academic staff in Engineering Colleges of Moradabad.

\section{OBJECTIVES OF THE STUDY}

The present study is the following Objectives

1. To identify frequency in the use of e-resources

2. To know the level of satisfaction among the students and scholars

3. To identify various format usage in e-resources

4. To find out the respondents using different type of eresources

5. To examine the problem in access and utilization of e-resources.

\section{IV.SAMPLE OF THE STUDY}

Annamalai University has 49 departments and 10 faculties out of which 10 departments have been selected for the purpose of present study viz Arts and Science, Education and Indian Languages only.

\section{V.DATA COLLECTION}

The researcher has employed a well structured questionnaire for collecting the data from the 10 departments selected from the study. For each department, questionnaires given to selected twenty five students and scholars. In total out of 250, 200 respondents selected under simple random sampling.

\section{VI.ANALYSIS AND DISCUSSION}

TABLE 1 DISTRIBUTION OF SAMPLE RESPONDENTS

\begin{tabular}{|c|c|c|c|c|}
\hline Category & $\begin{array}{c}\text { Questionnaire } \\
\text { distributed }\end{array}$ & $\%$ & $\begin{array}{c}\text { Questionnaire } \\
\text { received }\end{array}$ & $\%$ \\
\hline $\begin{array}{c}\text { P.G } \\
\text { Students }\end{array}$ & 120 & 48.00 & 100 & 50.00 \\
\hline $\begin{array}{c}\text { M.Phil. } \\
\text { Scholars }\end{array}$ & 80 & 32.00 & 60 & 30.00 \\
\hline $\begin{array}{c}\text { Ph.D. } \\
\text { Scholars }\end{array}$ & 50 & 20.00 & 40 & 20.00 \\
\hline Total & 250 & 100.00 & 200 & 100.00 \\
\hline
\end{tabular}


An Analytical Study on the Use of Electronic Resources by the Students and Research Scholars of Annamalai University,

Table 1 presents the distribution of the sample respondents. It shows the percentage of P.G Students, M.Phil. Scholars and Ph.D. Scholars of Annamalai University, Chidambaram, who participated in the study. Questionnaire were distributed to 250 users and 200 (80.00\%) responded to the survey.

TABLE 2 GENDER WISE RESPONDENTS

\begin{tabular}{|c|c|c|c|c|}
\hline Category & Male & \% & Female & \% \\
\hline $\begin{array}{c}\text { P.G } \\
\text { Students }\end{array}$ & 80 & 51.28 & 20 & 45.45 \\
\hline M.Phil. Scholars & 42 & 26.93 & 18 & 40.91 \\
\hline $\begin{array}{c}\text { Ph.D. } \\
\text { Scholars }\end{array}$ & 34 & 21.79 & 6 & 13.64 \\
\hline Total & 156 & 100.00 & 44 & 100 \\
\hline
\end{tabular}

Table 2 reveals the gender wise response of P.G Students and Scholars of Annamalai University. Among 80 (51.28\%) P.G Student respondents, 20 (45.45\%) are female, which is very less comparatively. 42 (26.93) M.Phil. Scholars were participated in the study, in which 18 (40.91) are female. Ph.D. scholar respondents are 34 (21.79) and about 6 (13.64) are female.

It could be seen clearly from the above discussion, majority of the respondents are males.

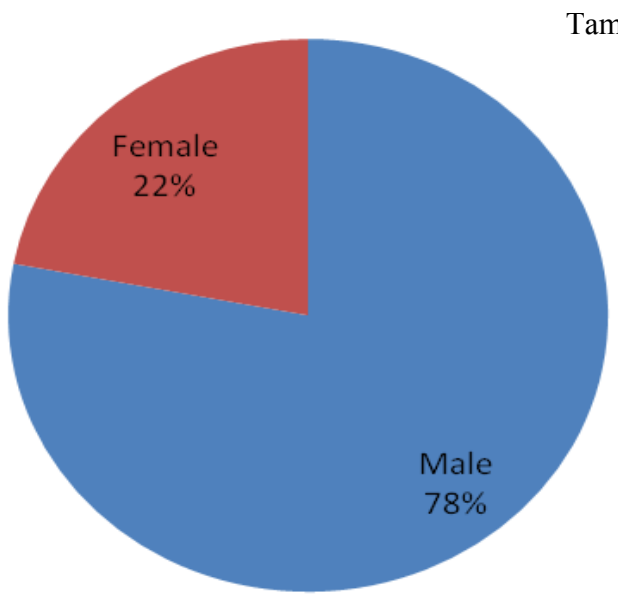

Fig.1 Gender wise Respondents

TABLE 3 BASED ON AWARENESS ABOUT E-RESOURCES

\begin{tabular}{|c|c|c|}
\hline Category & $\begin{array}{c}\text { No. of } \\
\text { respondents }\end{array}$ & \% \\
\hline Yes & 170 & 85.00 \\
\hline No & 30 & 15.00 \\
\hline Total & 200 & 100.00 \\
\hline
\end{tabular}

Table 3 shows that more than $85 \%$ of respondents are having knowledge in e-resources and there is $15.00 \%$ of the respondents do not no the usage of e-resources.

TABLE 4 FREQUENCY OF VISIT TO THE LIBRARY

\begin{tabular}{|c|c|c|c|c|c|c|}
\hline Frequency & $\begin{array}{c}\text { P.G } \\
\text { Students }\end{array}$ & $\mathbf{\%}$ & $\begin{array}{c}\text { M.Phil. } \\
\text { Scholars }\end{array}$ & $\mathbf{\%}$ & $\begin{array}{c}\text { Ph.D } \\
\text { Scholars }\end{array}$ & \% \\
\hline Daily & 65 & 65.00 & 40 & 66.67 & 24 & 60.00 \\
\hline Twice a day & 15 & 15.00 & 05 & 8.33 & 06 & 15.00 \\
\hline Weekly & 06 & 06.00 & 03 & 5.00 & 04 & 10.00 \\
\hline Monthly & 10 & 10.00 & 07 & 11.67 & 02 & 05.00 \\
\hline Occasionally & 04 & 04.00 & 05 & 8.33 & 04 & 10.00 \\
\hline Total & 100 & 100.00 & 60 & 100.00 & 40 & 100.00 \\
\hline
\end{tabular}

Table 4 reveals the frequency of visit to the library. $66.67 \%$ M.Phil. Scholars visit the university library daily, while $65 \%$ of P.G Students and $60 \%$ of the Ph.D. Scholars also uses Annamalai University library daily. It could be seen clearly from the above discussion that at least 60\% the P.G Students and Scholars use the library daily.

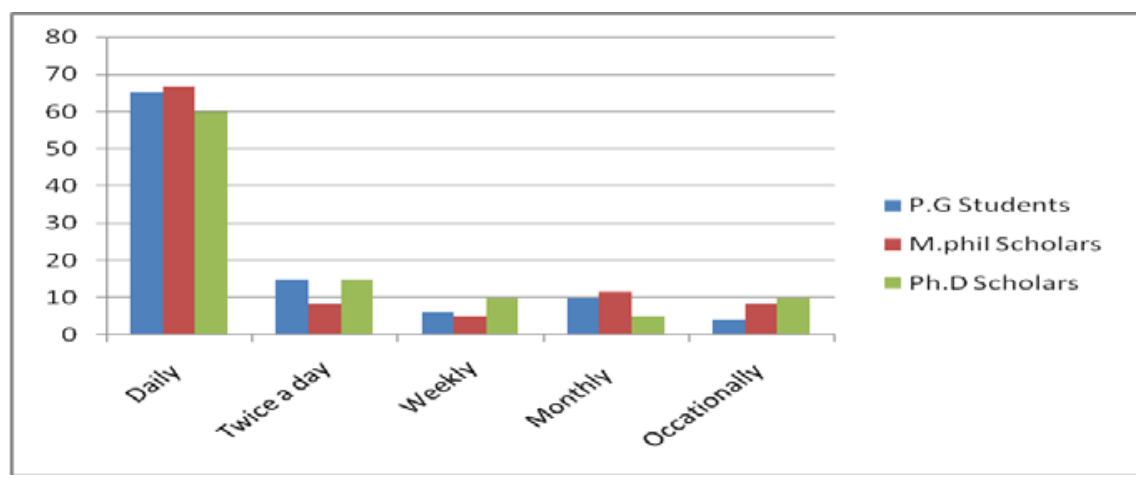

Fig. 2 Frequency of visit to the library 
TABLE 5 TYPES OF E-RESOURCES

\begin{tabular}{|c|c|c|c|c|c|c|c|}
\hline Frequency & $\begin{array}{c}\text { P.G } \\
\text { Students }\end{array}$ & $\mathbf{\%}$ & M.Phil. Scholars & $\mathbf{\%}$ & Ph.D Scholars & $\mathbf{\%}$ & Total \\
\hline E-journals & 60 & 60.00 & 29 & 48.33 & 25 & 62.50 & 114 \\
\hline E-books & 19 & 19.00 & 10 & 16.67 & 5 & 12.50 & 34 \\
\hline E-theses & 10 & 10.00 & 11 & 18.33 & 8 & 20.00 & 29 \\
\hline E- magazines & 6 & 6.00 & 8 & 13.33 & - & - & 14 \\
\hline E-encyclopedias & 5 & 5.00 & 2 & 3.34 & 2 & 5.00 & 9 \\
\hline Total & 100 & 100.00 & 60 & 100.00 & 40 & 100 & 200 \\
\hline
\end{tabular}

Table 5 exhibits the type of e-resources used by the respondents. Among the P.G Student respondents 60.00\% of them uses E-journals, $19.00 \%$ of them uses E-books, 10\% uses E-theses, 06\% E- magazines and 5\% Eencyclopedias as preferred E-resources. Among the M.Phil. Scholars 29 out of 60 uses E-journals, 10 out of 60 of them uses E-books, 11 out of 60 uses E-theses, 8 out of 60
E- magazines and 2 out of 60 E-encyclopedias as preferred E-resources. While among the 40 majority Ph.D Scholars 25 uses E-journals, 5 uses E-books, 8 uses E-theses and only 2 uses E-encyclopedias as preferred E-resources. None of the Ph.D. scholar uses E- magazines. It is inferred from the above table that maximum of P.G Students, M.Phil. Scholars and Ph.D. Scholars use E-Journals.

TABLE 6 REASONS USING THE E-RESOURCES

\begin{tabular}{|c|c|c|c|c|c|c|c|c|}
\hline Option & $\begin{array}{c}\text { P.G } \\
\text { Students }\end{array}$ & $\mathbf{\%}$ & $\begin{array}{c}\text { M.Phil. } \\
\text { Scholars }\end{array}$ & $\mathbf{\%}$ & $\begin{array}{c}\text { Ph.D } \\
\text { Scholars }\end{array}$ & \% & Total & \% \\
\hline Subject related & 75 & 71.42 & 40 & 38.09 & 30 & 28.57 & 105 & 52.50 \\
\hline My research work & 15 & & 10 & & 5 & & 30 & 15.00 \\
\hline
\end{tabular}

Data in table 6 reveals reasons for using e-resources. Out of 200 respondents, majority of the P.G Students, M.Phil. Scholars and Ph.D. Scholars opines for using the e-resources to subject related $(71.42 \%, 38.09 \%$ and $28.57 \%$.) and followed by career development and article publication respectively.

\section{VII.FINDINGS}

1. Most of the respondents are male.

2. Most of the respondents (85\%) have knowledge about e-resources.

3. It is found that most of the respondents visits the library daily for gathering recent information.

4. Most of the respondents (Students and Scholars) were satisfied with the usage of e-journals collection in the university library.

5. Most of respondents are aware of subject related information.

\section{VIII.CONCLUSION}

The survey provides knowledge about the respondents and usage of e-resources in the university library. This is quite natural in the present environment, Most of them uses of ejournals irrespective of their category. Some of the eresources such as e-theses, e-magazines and eencyclopedias are less used. It is concluded that, the users access behaviour and their utilization of e-resources provides a motivation for younger generation for improving the printed sources to electronic sources.

\section{REFERENCES}

[1] Haridasan, Sudharma and Khan, majid," Impact and use of eresources by social scientists in national social science documentation Centre (NASSDOC)”, Indian, Electronic Library, Vol. 27, No. 1, pp. 117-133, 2009.

[2] Tahira, M and Ameen, K, "Information needs and seeking behavior of science and technology teachers of the university of the Punjab, Lahore", Pakistan Journal of Library and Information Science, Vol. 10, pp. 80-96, 2009.

[3] Singh, Tanwar Sunder, "Digital preservation - Why and How? Pearl”, A Journal of library and Information Science, Vol. 6, No. 2, pp. 83-88, 2012.

[4] Mostofa, S.K, Mamum, “A study of information needs and seeking behavior of faculty members of Darullhsan University in Bangladesh”, Library Philosophy and Practice E-journal, 2016.

[5] http :// www.dli.ernet. In/static//dli/about dli:html.

[6] www.arl.org/access/scholars portal/may 01 rept.html. 